J. Dairy Sci. 92:3211-3221

doi:10.3168/jds.2008-1306

(c) American Dairy Science Association, 2009.

\title{
Effects of dietary forage level and monensin on lactation performance, digestibility and fecal excretion of nutrients, and efficiency of feed nitrogen utilization of Holstein dairy cows
}

\author{
C. M. Martinez, ${ }^{*}$ Y.-H. Chung, ${ }^{*}$ V. A. Ishler, ${ }^{*}$ K. W. Bailey,† and G. A. Varga*1 \\ ${ }^{*}$ Department of Dairy and Animal Science, and \\ †Department of Agricultural Economics and Rural Sociology, The Pennsylvania State University, University Park 16802
}

\begin{abstract}
Two experiments (Exp. 1 and 2) were conducted using a $4 \times 4$ Latin square design with 2 replications $(\mathrm{n}=8)$ to evaluate effects of feeding Holstein dairy cows a total mixed ration containing 50 or $60 \%$ of ration dry matter (DM) from forages with or without supplementation of monensin. In Exp. 1, alfalfa silage (AS) was used as the major forage ( $55 \%$ forage $\mathrm{DM})$, and corn silage (CS; $45 \%$ forage DM) was used to make up the rest of the forage portion of diets (55AS:45CS). In Exp. 2, CS was used as the major forage $(70 \%$ forage $\mathrm{DM}$ ) and alfalfa hay (AH; $30 \%$ forage $\mathrm{DM}$ ) was used to make up the rest of the forage portion of diets (70CS:30AH). Experimental diets were arranged in a $2 \times 2$ factorial with 50 or $60 \%$ ration DM from forages and monensin supplemented at 0 or $300 \mathrm{mg} / \mathrm{cow}$ daily. In Exp. 1 (55AS:45CS), feeding $60 \%$ forage diets decreased DM intake (DMI; 27.3 vs. $29.6 \mathrm{~kg} / \mathrm{d}$ ) but maintained the same levels of milk ( $45.8 \mathrm{vs} .47 .0 \mathrm{~kg} / \mathrm{d}$ ) compared with $50 \%$ forage diets. The efficiency of converting feed to milk or $3.5 \%$ fat-corrected milk was greater for cows fed $60 \%$ compared with $50 \%$ forage diets (1.7 vs. $1.6 \mathrm{~kg}$ milk or $3.5 \%$ fat-corrected milk $/ \mathrm{kg}$ of DMI, respectively). Increasing dietary forage level from 50 to $60 \%$ of ration DM increased milk fat percentage (3.4 to $3.5 \%$ ); however, adding monensin to the $60 \%$ forage diet inhibited the increase in milk fat percentage. Feeding $60 \%$ forage diets decreased feed cost, but this decrease ( $\$ 0.5 /$ head per day) in feed cost did not affect income over feed cost. Feeding $60 \%$ forage diets decreased fecal excretion of DM (10.6 to $9.6 \mathrm{~kg} / \mathrm{d}$ ) and nitrogen ( ; 354 to $324 \mathrm{~g} / \mathrm{d}$ ) and improved apparent digestibility of neutral detergent fiber from 43 to $49 \%$ and apparent efficiency of feed $\mathrm{N}$ utilization from 32.3 to $35.9 \%$ compared with $50 \%$ forage diets. In Exp. 2 (70CS:30AH), feeding $60 \%$ forage diets decreased DMI from 29.6 to $28.2 \mathrm{~kg}$ but maintained the same level of
\end{abstract}

Received April 27, 2008.

Accepted February 18, 2009.

${ }^{1}$ Corresponding author: gvarga@psu.edu milk (41.1 vs. $40.8 \mathrm{~kg} / \mathrm{d}$ ) and therefore increased the efficiency of converting feed to milk (1.46 vs. $1.38 \mathrm{~kg}$ milk/kg DMI) compared with $50 \%$ forage diets. Daily feed cost for feeding $60 \%$ forage diets was $\$ 0.3 /$ head lower than for the $50 \%$ forage diets. Fecal excretion of DM (10.3 vs. $11.5 \mathrm{~kg} / \mathrm{d}$ ) was lower and fecal excretion of N (299 vs. $328 \mathrm{~g} / \mathrm{d}$ ) tended to be lower for $60 \%$ compared with $50 \%$ forage diets. Results from these 2 experiments suggest that a $60 \%$ forage diet consisting of either AS or CS as the major forage can be fed to high producing Holstein dairy cows without affecting milk production while improving or maintaining the efficiency of converting feed to milk and the apparent efficiency of utilization of feed $\mathrm{N}$. Cows receiving a $60 \%$ forage diet had a similar or improved digestibility of nutrients with a similar or reduced fecal excretion of nutrients. Effects of monensin under the conditions of the current experiments were minimal.

Key words: dietary forage level, monensin, alfalfa silage, corn silage

\section{INTRODUCTION}

Feeding diets containing more than $50 \%$ of ration DM as forage to high producing dairy cows has been shown to support similar levels of milk production (Cherney et al., 2004) when compared with diets containing less forage DM. High quality forages that are high in digestibility and can be consumed in greater amounts than low quality forages (high NDF and low digestibility) are key in establishing high forage feeding systems (Llamas-Lamas and Combs, 1991). Monensin when fed to lactating dairy cows has been shown to shift the acetate to propionate ratio toward more propionate production, decrease methanogenesis (Russell and Houlihan, 2003), elicit an antiketogenic effect (Duffield and Bagg, 2000), and increase milk production (McGuffey et al., 2001). However, other studies have shown reductions in percentages of milk fat (Van Der Werf et al., 1998; Phipps et al., 2000) and protein (Phipps et al., 2000) for cows fed diets supplemented with monensin. Effects of monensin on performance of dairy cows can vary 
with the type of diet being fed (Ruiz et al., 2001), and therefore it is important to evaluate the effects of feeding monensin under different scenarios such as forage source and level of inclusion in the diet. The objectives of this study were to examine effects of feeding high producing Holstein dairy cows 2 dietary forage levels with or without monensin supplementation on DMI, milk production and composition, apparent digestibility and fecal excretion of nutrients, and apparent efficiency of feed $\mathrm{N}$ utilization.

\section{MATERIALS AND METHODS}

\section{Experimental Design, Allocation, and Dietary Treatments}

Two experiments (Exp.; designated as Exp. 1 and 2) were conducted to evaluate effects of dietary forage level with monensin supplementation on feed intake, milk production and composition, digestibility and fecal excretion of nutrients, and efficiency of intake $\mathrm{N}$ utilization of Holstein dairy cows. Either alfalfa silage (AS; Exp. 1) or corn silage (CS; Exp. 2) was used as the major forage source for formulating experimental diets. Each experiment was conducted as a $4 \times 4$ Latin square design with 2 replications using 8 multiparous Holstein dairy cows with a $2 \times 2$ factorial arrangement of treatments (dietary forage level at 50 or $60 \%$ of ration DM with or without monensin supplementation). Each experimental period was $4 \mathrm{wk}$ in length, which included a 3-wk feeding period and a 1-wk sampling period.

Cows were selected based on the following criteria: 1) milk fat $>3.5 \%, 2$ ) no milk protein percentage and fat percentage inversions for all available tests including the current lactation, and 3) between 50 to 150 DIM. In Exp. 1, cows (lactation number $=2.4 \pm 0.5$ SD) were at $104 \mathrm{DIM}( \pm 26.9 \mathrm{SD})$ at the beginning of the experiment with $13,121 \mathrm{~kg}( \pm 1,446.7 \mathrm{SD})$ of $305-\mathrm{d}$ mature-equivalent milk production and $698 \mathrm{~kg}( \pm 54.8$ SD) of initial BW. In Exp. 2, cows (lactation number $=3.0 \pm 1.2 \mathrm{SD})$ were at $139 \mathrm{DIM}( \pm 7.5 \mathrm{SD})$ at the beginning of the experiment with $13,264 \mathrm{~kg}( \pm 1,295.0$ $\mathrm{SD})$ of 305-d mature-equivalent milk production and $708 \mathrm{~kg}( \pm 63.5 \mathrm{SD})$ of initial BW.

Within each experiment, diets were formulated to be isocaloric and isonitrogenous and contained 50 or $60 \%$ forage (ration DM basis). In Exp. 1, AS was used as the major forage ( $55 \%$ forage DM) and CS was used to make up the rest of the forage portion of the diets ( $45 \%$ forage DM; Table 1). In Exp. 2, CS was used as the major forage ( $70 \%$ forage DM) and alfalfa hay (AH) was used to make up the rest of the forage portion of the diets (30\% forage DM; Table 2). The same
CS source was used for both experiments. Experiments were designated as 55AS:45CS (Exp. 1) or 70CS:30AH (Exp. 2). Within each experiment, treatments were designated as 50 or $60 \%$ forage diet with $(+)$ or without (-) monensin supplementation. Monensin (Kent Feeds, Muscatine, IA) was top dressed at a rate of 300 $\mathrm{mg} / \mathrm{cow}$ daily. Supplementing monensin as a top dress rather than as a component of the TMR provided an opportunity to control monensin consumption by each cow, and most cows readily consumed the top dress. All diets were formulated based on NRC (2001) guidelines for Holstein dairy cows at $636 \mathrm{~kg}$ of BW and producing $39 \mathrm{~kg}$ of milk/d with $3.7 \%$ of milk fat.

\section{Feeding and Management of Cows}

The Pennsylvania State University Animal Care and Use Committee approved all the animal protocols involved in these experiments. Cows were housed in a tunnel-ventilated tie-stall facility during the duration of the experiments. The experimental diets were fed as a TMR and fed once daily for ad libitum intake at approximately $0800 \mathrm{~h}$. Feed refusals were measured before feeding, and the amount of feed offered was adjusted to allow a $10 \%$ refusal. Feed was pushed up to cows approximately 4 to 6 times daily. Diets were adjusted weekly for changes in forage DM. Cows had free access to water at all times. Cows were milked at 0600 and $1800 \mathrm{~h}$ daily and had access to an exercise lot $1 \mathrm{~h}$ before each milking. Monensin was top dressed onto the fresh TMR after cows returned from the morning milking.

\section{Sample Collection and Analytical Procedures}

Samples of the TMR were collected weekly. Feed intake for each cow was recorded daily and adjusted by the DM percentage of the weekly TMR to calculate DMI. Body weights were recorded daily after each milking.

During the last week of each experimental period, forages, TMR, and refusals were sampled for 4 consecutive days, composited, and subsampled. Total mixed ration and refusal subsamples were analyzed for particle size distribution using the New Penn State Forage Particle Separator (Nasco, Fort Atkinson, WI). Fecal grab samples were taken every $6 \mathrm{~h}$ for 3 consecutive days during the last week of each experimental period to represent a 2 -h collection interval for a 24 -h period. A composited fecal sample was taken by subcompiling $100 \pm 5 \mathrm{~g}$ of fecal samples from each time point.

Forage, TMR, and refusal composited samples and the weekly TMR samples were dried at $55^{\circ} \mathrm{C}$ in a forced air oven for $48 \mathrm{~h}$ and fecal composited samples for one week. Dried forage, TMR, refusal, and fecal compos- 
Table 1. Ingredient and chemical composition of the experimental diets used in Exp. 1

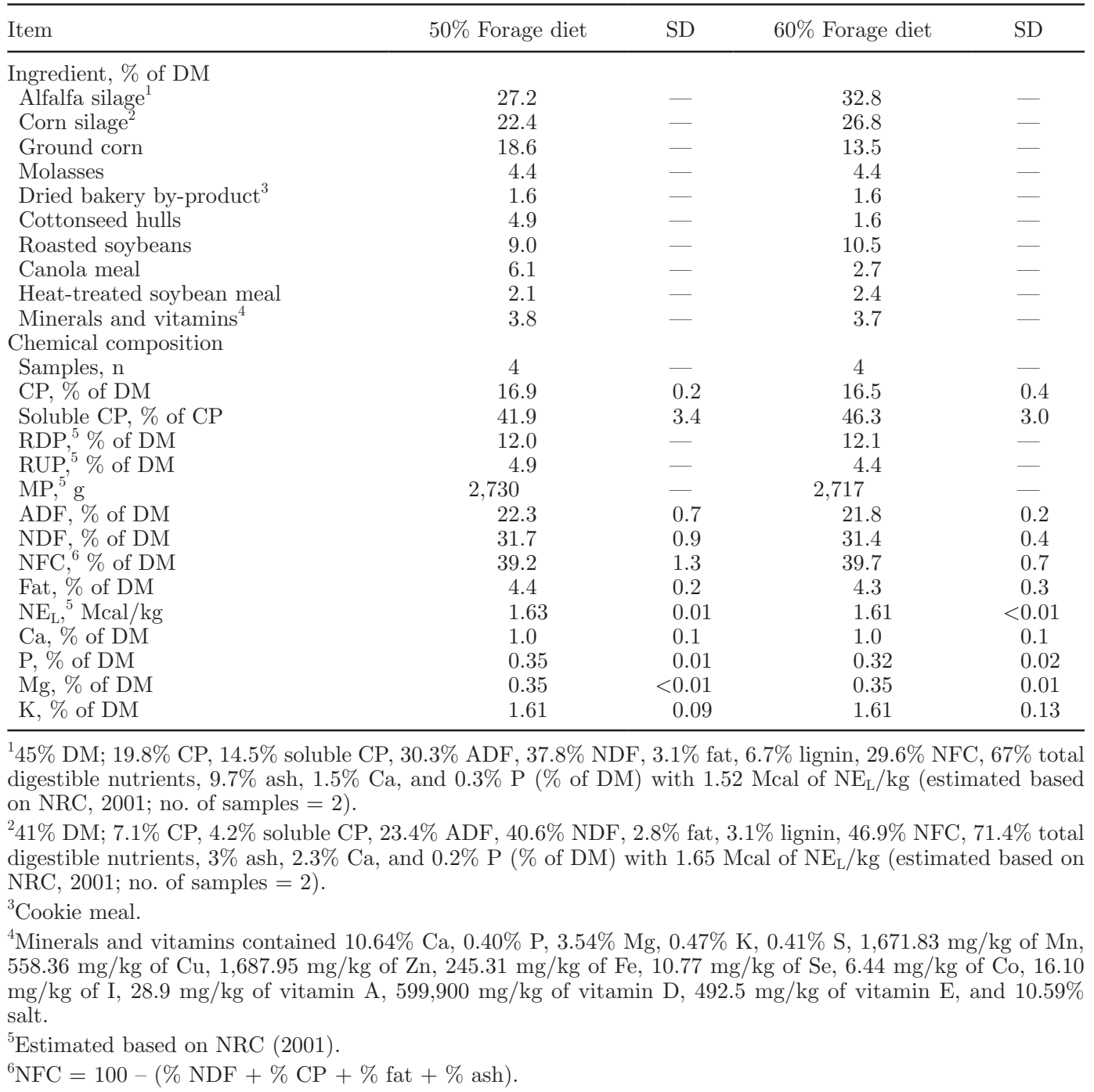

ited samples were ground using a Wiley Mill (Thomas Scientific, Philadelphia, PA) through a 1-mm screen. Ground TMR composited samples were analyzed for $\mathrm{DM}, \mathrm{CP}$, soluble CP, ADF, NDF, fat, and minerals using wet chemistry (Cumberland Valley Analytical Services, Maugansville, MD). Ground forage composited samples were analyzed for DM, CP, soluble CP, ADF, NDF, fat, lignin, total digestible nutrients, ash, and minerals. Ground refusal and fecal subsamples were analyzed for DM, CP, and NDF.

Dry matter was determined by drying at $135^{\circ} \mathrm{C}$ for 3 h (method 930.15; AOAC, 2005). Nitrogen was determined by combustion (method 990.03; AOAC, 2005; Leco FP-528 Combustion analyzer, Leco Instruments Inc., St. Joseph, MI) and multiplied by 6.25 to obtain CP. Soluble CP was determined using a borate-phosphate buffer procedure (Roe and Sniffen, 1990). Acid detergent fiber and NDF were determined using the
Ankom A200 filter bag technique (Ankom Technology, Macedon, NY) according to Van Soest et al. (1991) with heat-stable amylase and sodium sulfite used in the NDF procedure. Fat was determined by using a Soxtec system (System HT 1043 extraction unit, Tecator Soxtec, Eden Prairie, MN; method 2003.05; AOAC, 2005). Lignin was determined according to Goering and Van Soest (1970). Minerals were determined using inductively coupled plasma mass spectrometry (3300 XL and 5300 DV ICP, Perkin Elmer, Shelton, CT) with modifications (method 985.01; AOAC, 2000).

Indigestible NDF was used as the internal marker to calculate fecal excretion and apparent digestibility of nutrients. The indigestible NDF contents of the composited TMR and fecal samples were determined using in situ incubation (Lykos and Varga, 1995). Five rumencannulated cows in mid lactation $(185 \mathrm{DIM} \pm 15 \mathrm{SE})$ consuming a $50 \%$ (ration DM) forage diet were used. 
Table 2. Ingredient and chemical composition of the experimental diets used in Exp. 2

\begin{tabular}{|c|c|c|c|c|}
\hline Item & $50 \%$ Forage diet & $\mathrm{SD}$ & $60 \%$ Forage diet & $\mathrm{SD}$ \\
\hline \multicolumn{5}{|l|}{ Ingredient, $\%$ of DM } \\
\hline Corn silage $^{1}$ & 34.7 & - & 41.6 & - \\
\hline Alfalfa hay ${ }^{2}$ & 14.9 & - & 17.9 & - \\
\hline Ground corn & 15.6 & - & 11.4 & - \\
\hline Molasses & 4.4 & - & 4.4 & - \\
\hline Dried bakery by-product ${ }^{3}$ & 4.1 & - & 2.5 & - \\
\hline Cottonseed hulls & 6.5 & - & 2.8 & - \\
\hline Roasted soybeans & 8.4 & - & 10.1 & - \\
\hline Canola meal & 4.8 & - & 3.5 & - \\
\hline Heat-treated soybean meal & 1.7 & - & 1.4 & - \\
\hline Minerals and vitamins ${ }^{4}$ & 4.8 & - & 4.4 & - \\
\hline \multicolumn{5}{|l|}{ Chemical composition } \\
\hline Samples, $\mathrm{n}$ & 4 & - & 4 & - \\
\hline $\mathrm{CP}, \%$ of $\mathrm{DM}$ & 14.6 & 0.23 & 14.6 & 1.09 \\
\hline Soluble CP, $\%$ of $\mathrm{CP}$ & 37.8 & 1.1 & 39.7 & 2.6 \\
\hline $\mathrm{RDP}^{5} \%$ of $\mathrm{DM}$ & 10.1 & - & 10.2 & - \\
\hline $\mathrm{RUP}^{5} \%$ of DM & 4.6 & - & 4.4 & - \\
\hline $\mathrm{MP}^{5}{ }^{5} \mathrm{~g}$ & 2,681 & - & 2,676 & - \\
\hline $\mathrm{ADF}, \%$ of $\mathrm{DM}$ & 23.3 & 0.8 & 23.4 & 1.4 \\
\hline $\mathrm{NDF}, \%$ of DM & 35.1 & 2.6 & 34.0 & 1.5 \\
\hline $\mathrm{NFC}, 6 \%$ of DM & 38.9 & 2.5 & 39.6 & 0.3 \\
\hline Fat, $\%$ of DM & 3.8 & 0.2 & 3.7 & 0.4 \\
\hline $\mathrm{NE}_{\mathrm{L}},{ }^{5} \mathrm{Mcal} / \mathrm{kg}$ & 1.61 & 0.01 & 1.58 & 0.01 \\
\hline $\mathrm{Ca}, \%$ of $\mathrm{DM}$ & 0.94 & 0.08 & 1.02 & 0.05 \\
\hline $\mathrm{P}, \%$ of $\mathrm{DM}$ & 0.34 & 0.04 & 0.31 & 0.01 \\
\hline $\mathrm{Mg}, \%$ of $\mathrm{DM}$ & 0.33 & 0.03 & 0.31 & 0.03 \\
\hline $\mathrm{K}, \%$ of $\mathrm{DM}$ & 1.54 & 0.19 & 1.58 & 0.14 \\
\hline \multicolumn{5}{|c|}{$\begin{array}{l}{ }^{1} 41 \% \mathrm{DM} ; 7.1 \% \mathrm{CP}, 4.2 \% \text { soluble } \mathrm{CP}, 23.4 \% \mathrm{ADF}, 40.6 \% \mathrm{NDF}, 2.8 \% \text { fat, } 3.1 \% \text { lignin, } 46.9 \% \mathrm{NFC}, 71.4 \% \text { total } \\
\text { digestible nutrients, } 3 \% \text { ash, } 2.3 \% \mathrm{Ca} \text {, and } 0.2 \mathrm{P} \% \text { ( } \% \text { of DM) with } 1.65 \mathrm{Mcal} \text { of } \mathrm{NE}_{\mathrm{L}} / \mathrm{kg} \text { (estimated based on } \\
\text { NRC. 2001: no. of samples = } 2 \text { ). }\end{array}$} \\
\hline \multirow{2}{*}{\multicolumn{5}{|c|}{$\begin{array}{l}{ }^{2} 86 \% \mathrm{DM} ; 16.1 \% \mathrm{CP}, 6.5 \% \text { soluble } \mathrm{CP}, 37.5 \% \mathrm{ADF}, 46.3 \% \mathrm{NDF}, 1.8 \% \text { fat, } 8.2 \% \text { lignin, } 28.5 \% \mathrm{NFC}, 59.1 \% \text { total } \\
\text { digestible nutrients, } 8.7 \% \text { ash, } 1.7 \% \mathrm{Ca} \text {, and } 0.2 \% \mathrm{P} \text { ( } \% \text { of DM) with } 1.34 \mathrm{Mcal} \text { of } \mathrm{NE}_{\mathrm{L}} / \mathrm{kg} \text { (estimated based } \\
\text { on NRC, 2001; no. of samples = 1). }\end{array}$}} \\
\hline & & & & \\
\hline \multicolumn{5}{|c|}{$\begin{array}{l}{ }^{4} \text { Minerals and vitamins contained } 10.67 \% \mathrm{Ca}, 0.29 \% \mathrm{P}, 2.48 \% \mathrm{Mg}, 6.38 \% \mathrm{~K}, 0.29 \% \mathrm{~S}, 1,205.14 \mathrm{mg} / \mathrm{kg} \text { of } \mathrm{Mn} \text {, } \\
402.52 \mathrm{mg} / \mathrm{kg} \text { of } \mathrm{Cu}, 1,216.92 \mathrm{mg} / \mathrm{kg} \text { of } \mathrm{Zn}, 177.91 \mathrm{mg} / \mathrm{kg} \text { of Fe, } 7.18 \mathrm{mg} / \mathrm{kg} \text { of Se, } 4.70 \mathrm{mg} / \mathrm{kg} \text { of Co, } 11.76 \mathrm{mg} / \\
\mathrm{kg} \text { of I, } 28.9 \mathrm{mg} / \mathrm{kg} \text { of vitamin A, } 599,900 \mathrm{mg} / \mathrm{kg} \text { of vitamin D, } 457.5 \mathrm{mg} / \mathrm{kg} \text { of vitamin E, and } 7.67 \% \text { salt. } \\
{ }^{5} \mathrm{Estimated} \text { based on NRC }(2001) .\end{array}$} \\
\hline
\end{tabular}

After ruminal in situ incubation, TMR and fecal composited samples were analyzed for DM, CP, and NDF. In situ 12-d DM, CP, and NDF disappearance values were used to correct fecal output of DM, CP, and NDF originating from the TMR. This allowed for the calculation of DM, CP, and NDF digestibilities (Huhtanen et al., 1994). For each cow, apparent efficiency of feed $\mathrm{N}$ utilization (assuming no retention or mobilization of body $\mathrm{N}$ ) was calculated by dividing mean milk $\mathrm{N}$ output by mean N intake (Brito and Broderick, 2006).

Milk samples were taken for 4 consecutive milkings and preserved with 2-bromo-2-nitropropane-1,3-diol. Morning and evening samples were analyzed separately to adjust for different milk yields between morning and evening milkings. Milk samples were analyzed by Pennsylvania DHIA (University Park, PA) for content of fat, true protein, lactose, and MUN using infrared spectroscopic method (method 927.16; AOAC, 2005;
MilkoScan 4000, Foss Electric, Hillerød, Denmark) and SCC using an optical somatic cell counting method (method 978.26; AOAC, 2005; Fossomatic 400, Foss Electric).

Blood was sampled once from each cow during the last week of each experimental period at approximately $3 \mathrm{~h}$ after the morning feeding via venipuncture of the coccygeal vein into evacuated tubes (Becton Dickinson, Rutherford, NJ). Tubes that contained potassium oxalate and sodium fluoride were used for collecting plasma for analysis of glucose concentration. Tubes that contained sodium heparin were used for collecting plasma for analysis of BUN concentration. Serum separation tubes that contained a clot activator (polymer gel with silica activator) were used for collecting serum for analysis of insulin concentration. Blood tubes for plasma collection were immediately placed on ice and centrifuged within $1 \mathrm{~h}$ at $3,300 \times g$ for 15 min at $4^{\circ} \mathrm{C}$. 
Blood tubes for serum collection were allowed to remain at room temperature for $1 \mathrm{~h}$ to clot and then were centrifuged at $3,300 \times g$ for 15 min at room temperature. Plasma and serum samples were harvested and frozen at $-20^{\circ} \mathrm{C}$ for further analyses. Plasma samples were analyzed for glucose (Stanbio Enzymatic Glucose Kit 1075, Stanbio Laboratory Inc., Boerne, TX) based on the method of Trinder (1969), and for BUN (Stanbio Urea N Kit 580, Stanbio Laboratory Inc.). Serum insulin was determined by using an RIA (Coat-A-Count, Insulin kit TK1NX, Diagnostic Products Corp., Los Angeles, CA).

\section{Economic Analysis}

Income over feed costs (IOFC; Bailey et al., 2005) was used to estimate the economic effect of changes in dietary forage levels and monensin supplementation. Income over feed costs is a measure of gross profitability and accounts for the major sources of income (i.e., milk components) and expenses (i.e., feed). However, it does not reflect other sources of income such as premiums and cull sales, and other sources of expenses such as labor, veterinarian expense, and depreciation costs (Bailey et al., 2005). For experiments presented here, IOFC reflects the major changes in income and expenses from management changes related to feeding trials.

Feed prices were calculated using an average value of each ingredient during a 5-yr period for forages and 4 -yr period for commodities. The prices obtained from this data set represented the actual price paid for each ingredient in central Pennsylvania. The cost of a $22.7-\mathrm{kg}$ bag of the monensin premix was $\$ 17$ and contained 4.4 $\mathrm{g} / \mathrm{kg}$ of sodium monensin. Each cow was fed $68 \mathrm{~g} / \mathrm{d}$ of the premix, which provided $300 \mathrm{mg}$ of monensin. Based on this information, the price of monensin premix was $\$ 0.05 /$ cow per day, representing the actual price paid at the farm.

Milk component values were calculated using milk component prices obtained from the Agricultural Marketing Service (USDA, 2006) from January 2000 to May 2006. The value of IOFC calculated here only represented a response (i.e., milk volume and component levels) to changes in feed rations. The 5 -yr average price used in these experiments was $\$ 3.36 / \mathrm{kg}$ for milk fat, $\$ 4.77 / \mathrm{kg}$ for milk true protein, and $\$ 0.18 / \mathrm{kg}$ for other milk solids.

Income over feed costs was calculated individually for each cow. The equation used to calculate IOFC was as follows: $I O F C=M V-F C$, where $M V$ is milk value per cow $(\$ /$ cow $)$ per day and $F C$ is the cost of feed per cow $(\$ /$ cow $)$ per day required to produce the amount of milk in $M V$.
Milk value is defined as milk yield per day times the manufacturing value of milk: $M V=M Y \times(\% M F \times$ $\$ 3.36+\% T P \times \$ 4.77+\% O S \times \$ 0.18)$, where $M V$ is milk value per cow per day, $M Y$ is milk yield $(\mathrm{kg})$ per cow per day, $\% M F$ is percentage of milk fat, $\% T P$ is percentage of true protein, and $\% O S$ is percentage of other solids. Note that the manufacturing value of milk $(M V)$ is equal to the milk component levels multiplied by the 5 -yr average component values. This is similar to how dairy farmers are paid. Feed cost is calculated as $F C=\sum_{i} P^{i} \times Q^{i}$, where $F C$ is feed costs, $P$ is the price of feed ingredient $i$, and $Q$ is the daily quantity of feed ingredient $i$ consumed by the cow.

\section{Statistical Analysis}

For measurements taken serially, an average by treatment per period was obtained for statistical analysis. Response variables were analyzed as a $4 \times 4$ Latin square design with a $2 \times 2$ factorial treatment arrangement by using PROC MIXED (SAS Institute, 1999). The full statistical model included the fixed effects of square, period nested within square, forage level (50 or $60 \%$ of ration DM), monensin (with or without supplementation), and the interaction of forage level by monensin. If the fixed effect of square, period nested within square, or both was not significant $(P>0.05)$, it was removed from the full statistical model. Degrees of freedom were estimated by using the Kenward-Roger option in the MODEL statement. Cow nested within square was used in the RANDOM statement. The PDIFF option adjusted by Tukey method was used for multiple-comparison tests. Least squares means \pm standard errors of the means are reported for all data (unless otherwise expressed). Interactions and overall treatment differences were examined using the least squares means. Differences were declared significant at $P \leq 0.05$ and a tendency toward significance was discussed at $0.5<P \leq 0.10$.

\section{RESULTS}

\section{Particle Size Distribution}

In Exp. 1 (55AS:45CS), particle size distribution for the upper, middle, and lower sieves, and bottom pan, respectively, for $50 \%$ forage diets was $2,35,48$, and $15 \%$ of total $( \pm 1.8$ pooled SEM) over the duration of the experiment, and for $60 \%$ forage diets was 4,40 , 45 , and $11 \%$ of total ( \pm 4.9 pooled SEM). Particle size distribution for refusals of the $50 \%$ forage diets was 3 , 40,46 , and $12 \%$ of total ( \pm 1.6 pooled SEM), and for the $60 \%$ forage diets was $4,45,43,8 \%$ of total $( \pm 6.5$ pooled SEM). 
Table 3. Production performance for cows fed a 50 or $60 \%$ forage diet (ration DM) with (+) or without (-) monensin supplementation (Exp. 1)

\begin{tabular}{|c|c|c|c|c|c|c|c|}
\hline \multirow[b]{2}{*}{ Item } & \multicolumn{2}{|c|}{$50 \%$ Forage diet } & \multicolumn{2}{|c|}{$60 \%$ Forage diet } & \multirow[b]{2}{*}{ SEM } & \multicolumn{2}{|c|}{$P$-value } \\
\hline & - & + & - & + & & Forage level & Monensin \\
\hline DMI, kg/d & 29.3 & 30.0 & 27.5 & 27.1 & 0.95 & $<0.01$ & 0.77 \\
\hline DMI, $\%$ of BW & 4.13 & 4.28 & 3.94 & 3.96 & 0.16 & 0.02 & 0.39 \\
\hline $\mathrm{BW}, \mathrm{kg}$ & 712 & 709 & 701 & 694 & 14.20 & 0.02 & 0.33 \\
\hline Milk yield, $\mathrm{kg} / \mathrm{d}$ & 46.9 & 47.1 & 45.3 & 46.3 & 2.91 & 0.29 & 0.57 \\
\hline Feed efficiency ${ }^{1}$ & 1.60 & 1.57 & 1.65 & 1.73 & 0.08 & $<0.01$ & 0.48 \\
\hline $3.5 \% \mathrm{FCM}^{2}{ }^{2} \mathrm{~kg} / \mathrm{d}$ & 45.7 & 47.4 & 46.8 & 46.8 & 2.84 & 0.86 & 0.56 \\
\hline $3.5 \%$ FCM efficiency ${ }^{1}$ & 1.54 & 1.58 & 1.71 & 1.72 & 0.09 & 0.03 & 0.75 \\
\hline \multicolumn{8}{|l|}{ Milk component } \\
\hline Fat, ${ }^{3} \%$ & $3.33^{\mathrm{b}}$ & $3.46^{\mathrm{ab}}$ & $3.61^{\mathrm{a}}$ & $3.42^{\mathrm{ab}}$ & 0.13 & 0.04 & 0.64 \\
\hline Fat yield, $\mathrm{kg} / \mathrm{d}$ & 1.56 & 1.65 & 1.66 & 1.62 & 0.10 & 0.56 & 0.70 \\
\hline Protein, $\%$ & $3.13^{\mathrm{a}}$ & $3.11^{\mathrm{ab}}$ & $3.10^{\mathrm{ab}}$ & $3.03^{\mathrm{b}}$ & 0.06 & 0.02 & 0.03 \\
\hline Protein yield, $\mathrm{kg} / \mathrm{d}$ & 1.47 & 1.48 & 1.42 & 1.44 & 0.08 & 0.36 & 0.82 \\
\hline Lactose, \% & 4.83 & 4.83 & 4.79 & 4.77 & 0.07 & 0.11 & 0.74 \\
\hline Other solids, ${ }^{4} \%$ & 5.74 & 5.74 & 5.70 & 5.68 & 0.07 & 0.11 & 0.74 \\
\hline Total solids, ${ }^{3} \%$ & $12.20^{\mathrm{ab}}$ & $12.30^{\mathrm{ab}}$ & $12.41^{\mathrm{a}}$ & $12.13^{\mathrm{b}}$ & 0.16 & 0.73 & 0.20 \\
\hline $\mathrm{SCC}, \times 1,000 \mathrm{cell} / \mathrm{ml}$ & 174 & 188 & 404 & 261 & 208.5 & 0.12 & 0.50 \\
\hline MUN, mg/dL & 9.11 & 9.61 & 9.93 & 9.49 & 0.88 & 0.47 & 0.95 \\
\hline \multicolumn{8}{|l|}{ Daily economic analysis } \\
\hline Feed cost, $\$ /$ cow & 4.31 & 4.49 & 3.91 & 3.94 & 0.13 & $<0.01$ & 0.32 \\
\hline Milk value, \$/cow & 12.76 & 13.09 & 12.83 & 12.77 & 0.77 & 0.80 & 0.78 \\
\hline $\mathrm{IOFC},{ }^{5} \$ / \mathrm{cow}$ & 8.46 & 8.60 & 8.92 & 8.84 & 0.72 & 0.45 & 0.95 \\
\hline
\end{tabular}

\footnotetext{
${ }^{\mathrm{a}, \mathrm{b}}$ Means within a row with different superscripts differ $(P \leq 0.05)$.

${ }^{1}$ Feed or $3.5 \%$ FCM efficiency $=\mathrm{kg}$ of milk or $3.5 \% \mathrm{FCM} \div \mathrm{kg}$ of DMI.

${ }^{2} 3.5 \%$ FCM yield $=(0.4255 \times$ milk yield $)+[16.425 \times($ milk fat $\% \div 100) \times$ milk yield $]$, as in Gaines $(1928)$.

${ }^{3}$ Dietary forage level $\times$ monensin supplementation interaction $(P<0.05)$.

${ }^{4}$ Milk other solids $=$ lactose + minerals.

${ }^{5}$ Income over feed costs $(\mathrm{IOFC})=$ milk value $(\$ /$ cow $)-$ feed cost $(\$ /$ cow $)$.
}

In Exp. 2 (70CS:30AH), particle size distribution for the upper, middle, and lower sieves, and bottom pan, respectively, for $50 \%$ forage diets was $4,32,46$, and $18 \%$ ( \pm 5.2 pooled SEM) over the duration of the experiment, and for $60 \%$ forage diets was $5,35,45$, and $15 \%$ ( \pm 4.7 pooled SEM). Particle size distribution for refusals of the $50 \%$ forage diets was 3, 34, 50, and $13 \%$ of total ( \pm 5.7 pooled SEM), and for the $60 \%$ forage diets was $6,39,43,12 \%$ of total ( \pm 5.7 pooled SEM).

Recommendations for TMR particle size distribution are 2 to 8,30 to 50,30 to 50 , and $\leq 20 \%$ of total for the upper, middle, and lower sieves, and bottom pan, respectively, using the New Penn State Forage Particle Separator (Kononoff and Heinrichs, 2004). Particle size distributions observed for all experimental diets used and refusals collected in the current experiments were within the recommendations for TMR samples, and therefore sorting of the experimental diets was likely to be minimal.

\section{Experiment 1 (55AS:45CS)}

Feeding $60 \%$ forage diets decreased DMI $(P<0.01)$ and DMI as a percentage of BW $(P=0.02)$ compared with $50 \%$ forage diets $(27.3$ vs. $29.6 \mathrm{~kg} / \mathrm{d} \pm 0.8$ and 4.0 vs. $4.2 \% \pm 0.14$, respectively; Table 3 ). Cows weighed less $(P=0.02)$ when fed $60 \%$ compared with $50 \%$ forage diets (697 vs. $710 \mathrm{~kg} \pm 13.7$, respectively), likely because of a lower DMI. Even at a lower intake of DM, milk yield and $3.5 \%$ FCM for cows fed $60 \%$ forage diets were not different from cows fed $50 \%$ forage diets $(45.8$ vs. $47.0 \mathrm{~kg}$ milk/ $/ \mathrm{d} \pm 2.8$ and 46.8 vs. $46.5 \mathrm{~kg} 3.5 \%$ $\mathrm{FCM} / \mathrm{d} \pm 2.7$, respectively). Therefore, the efficiency of converting feed to milk or 3.5\% FCM was greater for cows fed $60 \%$ compared with $50 \%$ forage diets (1.7 vs. $1.6 \mathrm{~kg}$ milk or $3.5 \% \mathrm{FCM} / \mathrm{kg} \mathrm{DMI} \pm 0.1$, respectively). Supplementing monensin had no effects on DMI, BW, or milk yield.

Feeding diets at $60 \%$ dietary forage increased $(P=$ 0.04 ) milk fat percentage from 3.4 to $3.5 \% \pm 0.12$ compared with feeding diets at $50 \%$ dietary forage (Table 3 ). An interaction of dietary forage level by monensin supplementation was observed for milk fat percentage $(P=0.01)$. Milk from cows fed the $60 \%$ forage diet without monensin supplementation had a greater $(P$ $=0.01$ ) fat percentage then the milk from cows fed the $50 \%$ forage diet without adding monensin (3.6 vs. $3.3 \% \pm 0.1$, respectively). Feeding $60 \%$ forage diets $(P=0.02)$ or supplementing monensin $(P=0.03)$ decreased milk protein percentage; however, milk protein 
Table 4. Fecal excretion and apparent digestibility of nutrients and apparent efficiency of feed $\mathrm{N}$ utilization for cows fed a 50 or $60 \%$ forage diet (ration DM) with $(+)$ or without $(-)$ monensin supplementation (Exp. 1)

\begin{tabular}{|c|c|c|c|c|c|c|c|}
\hline \multirow[b]{2}{*}{ Item } & \multicolumn{2}{|c|}{$50 \%$ Forage diet } & \multicolumn{2}{|c|}{$60 \%$ Forage diet } & \multirow[b]{2}{*}{ SEM } & \multicolumn{2}{|c|}{$P$-value } \\
\hline & - & + & - & + & & Forage level & Monensin \\
\hline \multicolumn{8}{|l|}{ Fecal excretion ${ }^{1}$} \\
\hline $\mathrm{DM}, \mathrm{kg} / \mathrm{d}$ & 10.3 & 11.0 & 9.9 & 9.3 & 0.51 & 0.02 & 0.93 \\
\hline $\mathrm{N}, \mathrm{g} / \mathrm{d}$ & 349 & 360 & 336 & 312 & 16.8 & 0.04 & 0.64 \\
\hline \multicolumn{8}{|l|}{ Digestibility, \% } \\
\hline DM & 62.4 & 61.4 & 61.6 & 63.0 & 1.22 & 0.72 & 0.83 \\
\hline Milk $\mathrm{N}$ output, g/d & 251 & 250 & 240 & 242 & 14.1 & 0.29 & 0.96 \\
\hline Intake $\mathrm{N},{ }^{2} \mathrm{~g} / \mathrm{d}$ & 760 & 778 & 681 & 671 & 26.5 & $<0.01$ & 0.84 \\
\hline Feed $\mathrm{N}$ utilization efficiency, ${ }^{3} \%$ & 32.5 & 32.1 & 35.4 & 36.3 & 2.00 & 0.02 & 0.86 \\
\hline
\end{tabular}

${ }^{1}$ Fecal excretion calculated from indigestible NDF data.

${ }^{2}$ Intake $\mathrm{N}$ calculated using chemical analysis data.

${ }^{3}$ Feed $\mathrm{N}$ utilization efficiency $=$ milk $\mathrm{N}$ output $\div$ intake $\mathrm{N}$.

percentage for 50 or $60 \%$ forage diets with or without monensin was similar at $3.1 \% \pm 0.1$. The multiple comparison tests revealed that cows had a lower $(P \leq$ $0.5)$ milk protein percentage when fed the $60 \%$ forage diet supplemented with monensin than the $50 \%$ forage diet not supplemented with monensin (3.03 vs. $3.13 \%$ \pm 0.06 , respectively), although an interaction of dietary forage level by monensin supplementation was not significant. Milk total solids percentage was affected $(P$ $=0.01$ ) by the interaction of dietary forage level and monensin supplementation. This interaction was due to milk from cows fed the $60 \%$ forage diet with monensin supplementation having lower milk total solids percentage $(12.13 \%)$ than milk from cows fed the $60 \%$ forage diet without monensin supplementation (12.41\%). This lower milk total solids percentage for cows fed the $60 \%$ forage diet with monensin supplementation was likely a consequence of a numerically lower milk fat percentage and a lower milk protein percentage. Yields of milk fat and protein, percentages of milk lactose and other solids, SCC, and MUN were not affected by dietary forage level or monensin supplementation.

Daily feed cost was lower for $60 \%$ compared with $50 \%$ forage diets ( $\$ 3.9$ vs. $\$ 4.4 /$ cow \pm 0.11 , respectively; $P$ $<0.01$; Table 3). Milk values and IOFC, however, were similar between 50 and $60 \%$ forage diets, and adding monensin did not affect IOFC.

Feeding $60 \%$ forage diets decreased $(P<0.05)$ fecal excretion of $\mathrm{DM}$ and $\mathrm{N}$ and improved apparent digestibility of NDF from 43 to $49 \%$ ( \pm 1.3 ) compared with $50 \%$ forage diets, whereas digestibility of $\mathrm{DM}$ and $\mathrm{CP}$ was similar across dietary forage levels (Table 4). Fecal excretion of DM decreased from 10.6 to $9.6 \mathrm{~kg} / \mathrm{d}$ ( \pm 0.4 ) and fecal excretion of $\mathrm{N}$ from 354 to $324 \mathrm{~g} / \mathrm{d}$ ( \pm 14.5) by increasing dietary forage level from 50 to $60 \%$ of ration DM. Apparent efficiency of feed N utilization was improved $(P=0.02)$ from 32.3 to $35.9 \%( \pm 1.7)$ by feeding diets at $60 \%$ compared with $50 \%$ forage (ration DM). This improvement found in apparent efficiency of feed $\mathrm{N}$ utilization by feeding a higher forage diet from 50 to $60 \%$ of ration DM was due to a decrease $(P<0.01)$ in $\mathrm{N}$ intake that resulted from a lower DMI and a similar milk $\mathrm{N}$ output between the 2 dietary forage levels. Supplementing monensin had no effect on digestibility and fecal excretion of nutrients or apparent efficiency of feed $\mathrm{N}$ utilization.

Increasing dietary forage level from 50 to $60 \%$ (ration DM) decreased $(P<0.01)$ plasma glucose concentration $(3.8$ to $3.6 \mathrm{mmol} / \mathrm{L} \pm 23.6)$ and tended $(P<0.01)$ to decrease serum insulin concentration (142 to $92 \mathrm{pmol} / \mathrm{L}$ \pm 0.1 ) because of a lower intake of concentrate (Table 5). Blood urea nitrogen, however, was not affected by increasing dietary forage level from 50 to $60 \%$ (ration $\mathrm{DM})$.

\section{Experiment 2 (70CS:30AH)}

Feeding $60 \%$ forage diets decreased $(P=0.01)$ DMI from 29.6 to $28.2 \mathrm{~kg}( \pm 0.6)$ but not DMI as percentage of BW (4.0 vs. $4.2 \% \pm 0.1$ ) or BW (708 vs. $704 \mathrm{~kg} \pm$ $15.5)$ compared with feeding $50 \%$ forage diets, respectively (Table 6). Yields of milk (41.1 vs. $40.8 \mathrm{~kg} / \mathrm{d} \pm$ 2.3 for 60 vs. $50 \%$ forage diets, respectively) and $3.5 \%$ FCM (42.9 vs. $41.9 \mathrm{~kg} / \mathrm{d} \pm 1.7$ for 60 vs. $50 \%$ forage diets, respectively) were similar between dietary forage levels. Based on a lower intake of DM, feeding $60 \%$ forage diets increased $(P<0.01)$ the efficiency of converting feed to milk (1.46 vs. $1.38 \mathrm{~kg}$ milk $/ \mathrm{kg}$ DMI \pm 0.08 ) but not the efficiency of converting feed to $3.5 \%$ FCM compared with $50 \%$ forage diets. Supplementation of monensin did not affect feed intake, BW, or milk yield. 
Table 5. Concentration of blood metabolite and insulin for cows fed a 50 or $60 \%$ forage diet (ration DM) with (+) or without (-) monensin supplementation

\begin{tabular}{|c|c|c|c|c|c|c|c|}
\hline Item & \multicolumn{2}{|c|}{$50 \%$ Forage diet } & \multicolumn{2}{|c|}{$60 \%$ Forage diet } & SEM & \multicolumn{2}{|c|}{$P$-value } \\
\hline $\mathrm{BUN}, \mathrm{mmol} / \mathrm{L}$ & 5.4 & 5.3 & 5.4 & 5.2 & 0.34 & 0.85 & 0.59 \\
\hline Insulin, pmol/L & 129 & 155 & 104 & 79 & 32.1 & 0.10 & 1.00 \\
\hline \multicolumn{8}{|l|}{ Exp. 2} \\
\hline Insulin, $\mathrm{pmol} / \mathrm{L}$ & 133 & 94 & 98 & 97 & 21.8 & 0.47 & 0.38 \\
\hline
\end{tabular}

Dietary forage level or monensin supplementation had no effects on milk composition (Table 6). An interaction of dietary forage level by monensin supplementation was found on percentages of milk lactose $(P$ $=0.03)$ and milk other solids $(P=0.02)$. Supplementation of monensin tended to decrease percentages of milk lactose and milk other solids for cows fed $60 \%$ but not $50 \%$ forage diets (milk lactose: 4.60 vs. $4.69 \%$ for $60 \%$ and $50 \%$ forage diet, respectively, $P=0.09$; milk other solids: 5.51 vs. $5.60 \%$ for $60 \%$ and $50 \%$ forage diet, respectively, $P=0.09$ ). The effect of monensin on milk lactose percentage in $60 \%$ forage diets likely contributed to the effect of monensin on milk other solids percentage because milk other solids is a calculation of milk lactose plus minerals.

Daily feed cost for feeding $60 \%$ forage diets was lower $(P=0.04)$ than $50 \%$ forage diets ( $\$ 4.7$ vs. $\$ 5.0 /$ cow \pm 0.13 , respectively; Table 6 ). Milk values were similar between dietary forage level or monensin supplementation. Even at a lower feed cost, feeding $60 \%$ forage diets did not generate a greater IOFC compared with $50 \%$ forage diets. Adding monensin did not affect any of the economic analyses.

Fecal excretion of DM (10.3 vs. $11.5 \mathrm{~kg} / \mathrm{d} \pm 0.4)$ was lower $(P=0.05)$ and fecal excretion of N (299 vs. 328 $\mathrm{g} / \mathrm{d} \pm 11.1)$ tended to be lower $(P=0.06)$ for $60 \%$ com-

Table 6. Production performance for cows fed a 50 or $60 \%$ forage diet (ration DM) with (+) or without (-) monensin supplementation (Exp. 2)

\begin{tabular}{|c|c|c|c|c|c|c|c|}
\hline \multirow[b]{2}{*}{ Item } & \multicolumn{2}{|c|}{$50 \%$ Forage diet } & \multicolumn{2}{|c|}{$60 \%$ Forage diet } & \multirow[b]{2}{*}{ SEM } & \multicolumn{2}{|c|}{$P$-value } \\
\hline & - & + & - & + & & Forage level & Monensin \\
\hline DMI, kg/d & 29.8 & 29.5 & 28.2 & 28.2 & 0.73 & 0.01 & 0.73 \\
\hline DMI, $\%$ of BW & 4.24 & 4.13 & 4.08 & 3.98 & 0.11 & 0.15 & 0.32 \\
\hline $\mathrm{BW}, \mathrm{kg}$ & 706 & 703 & 712 & 704 & 16.30 & 0.64 & 0.49 \\
\hline Milk yield, kg/d & 40.6 & 40.9 & 41.1 & 41.1 & 2.45 & 0.76 & 0.87 \\
\hline Feed efficiency ${ }^{1}$ & 1.37 & 1.39 & 1.47 & 1.47 & 0.09 & $<0.01$ & 0.71 \\
\hline $3.5 \% \mathrm{FCM}^{2},{ }^{2} \mathrm{~kg} / \mathrm{d}$ & 42.7 & 41.1 & 44.1 & 41.6 & 1.90 & 0.46 & 0.14 \\
\hline $3.5 \%$ FCM efficiency ${ }^{1}$ & 1.43 & 1.42 & 1.52 & 1.50 & 0.07 & 0.17 & 0.72 \\
\hline \multicolumn{8}{|l|}{ Milk component } \\
\hline Fat, $\%$ & 3.72 & 3.64 & 3.70 & 3.76 & 0.18 & 0.55 & 0.87 \\
\hline Fat yield, kg/d & 1.52 & 1.45 & 1.58 & 1.49 & 0.07 & 0.42 & 0.20 \\
\hline Protein, $\%$ & 3.15 & 3.18 & 3.15 & 3.14 & 0.09 & 0.35 & 0.63 \\
\hline Protein yield, kg/d & 1.31 & 1.28 & 1.35 & 1.26 & 0.07 & 0.82 & 0.19 \\
\hline Lactose, ${ }^{3} \%$ & 4.64 & 4.69 & 4.67 & 4.60 & 0.06 & 0.26 & 0.70 \\
\hline Other solids, ${ }^{3,4} \%$ & 5.55 & 5.60 & 5.58 & 5.51 & 0.06 & 0.26 & 0.72 \\
\hline Total solids, $\%$ & 12.52 & 12.42 & 12.43 & 12.41 & 0.25 & 0.58 & 0.50 \\
\hline $\mathrm{SCC}, \times 1,000 \mathrm{cell} / \mathrm{mL}$ & 159 & 179 & 100 & 175 & 36.25 & 0.29 & 0.11 \\
\hline MUN, mg/dL & 7.72 & 8.01 & 8.07 & 8.17 & 0.46 & 0.47 & 0.59 \\
\hline \multicolumn{8}{|l|}{ Daily economic analysis } \\
\hline Feed cost, $\$ /$ cow & 5.03 & 4.96 & 4.77 & 4.67 & 0.16 & 0.04 & 0.51 \\
\hline Milk value, $\$ /$ cow & 11.91 & 11.39 & 12.16 & 11.41 & 0.60 & 0.77 & 0.18 \\
\hline $\mathrm{IOFC}^{5}, \$ / \mathrm{cow}$ & 6.87 & 6.43 & 7.40 & 6.74 & 0.54 & 0.34 & 0.21 \\
\hline
\end{tabular}

${ }^{1}$ Feed or $3.5 \% \mathrm{FCM}$ efficiency $=\mathrm{kg}$ of milk or $3.5 \% \mathrm{FCM} \div \mathrm{kg}$ of DMI.

${ }^{2} 3.5 \%$ FCM yield $=(0.4255 \times$ milk yield $)+[16.425 \times($ milk fat $\% \div 100) \times$ milk yield $]$, as in Gaines $(1928)$.

${ }^{3}$ Dietary forage level $\times$ monensin supplementation interaction $(P<0.05)$.

${ }^{4}$ Milk other solids $=$ lactose + minerals.

${ }^{5}$ Income over feed costs $(\mathrm{IOFC})=$ milk value $(\$ /$ cow $)-$ feed cost $(\$ /$ cow $)$. 
Table 7. Fecal excretion and apparent digestibility of nutrients and apparent efficiency of feed $\mathrm{N}$ utilization for cows fed a 50 or $60 \%$ forage diet (ration DM) with (+) or without (-) monensin supplementation (Exp. 2)

\begin{tabular}{|c|c|c|c|c|c|c|c|}
\hline \multirow[b]{2}{*}{ Item } & \multicolumn{2}{|c|}{$50 \%$ Forage diet } & \multicolumn{2}{|c|}{$60 \%$ Forage diet } & \multirow[b]{2}{*}{ SEM } & \multicolumn{2}{|c|}{$P$-value } \\
\hline & - & + & - & + & & Forage level & Monensin \\
\hline \multicolumn{8}{|l|}{ Fecal excretion ${ }^{1}$} \\
\hline $\mathrm{DM}, \mathrm{kg} / \mathrm{d}$ & 11.7 & 11.4 & 10.6 & 10.1 & 0.56 & 0.05 & 0.44 \\
\hline $\mathrm{N}, \mathrm{g} / \mathrm{d}$ & 330 & 326 & 311 & 287 & 15.2 & 0.06 & 0.35 \\
\hline \multicolumn{8}{|l|}{ Digestibility, \% } \\
\hline DM, $\%$ & 58.6 & 58.7 & 60.8 & 62.0 & 1.71 & 0.13 & 0.71 \\
\hline Milk $\mathrm{N}$ output, $\mathrm{g} / \mathrm{d}$ & 220 & 222 & 227 & 212 & 11.0 & 0.78 & 0.37 \\
\hline Intake $\mathrm{N},{ }^{2} \mathrm{~g} / \mathrm{d}$ & 663 & 655 & 640 & 619 & 24.8 & 0.20 & 0.52 \\
\hline Feed $\mathrm{N}$ utilization efficiency, ${ }^{3} \%$ & 33.1 & 33.5 & 35.7 & 34.2 & 1.82 & 0.25 & 0.69 \\
\hline
\end{tabular}

${ }^{1}$ Fecal excretion calculated from indigestible NDF data.

${ }^{2}$ Intake $\mathrm{N}$ calculated using chemical analysis data.

${ }^{3}$ Apparent efficiency of feed $\mathrm{N}$ utilization $=$ milk $\mathrm{N}$ output $\div$ intake $\mathrm{N}$.

pared with $50 \%$ forage diets, respectively, likely due to a lower DMI for $60 \%$ forage diets (Table 7). Apparent digestibility of nutrients stayed similar between 60 and $50 \%$ forage diets. Milk $\mathrm{N}$ output, $\mathrm{N}$ intake, or the apparent efficiency of feed $\mathrm{N}$ utilization was not affected by dietary forage level or monensin supplementation.

Feeding $60 \%$ forage diets did not affect blood glucose, BUN, or serum insulin even at a lower intake of grain compared with $50 \%$ forage diets (Table 5). Monensin supplementation had no effects on any blood parameters.

\section{DISCUSSION}

\section{Higher Dietary Forage Feeding}

The experiments presented here demonstrated that there is a potential for improving the efficiency of converting feed to milk and reducing fecal excretion of nutrients of high-producing Holstein dairy cows by increasing dietary forage level from 50 to $60 \%$ of ration DM using either AS or CS as the major forage. However, it should be noted that the conditions of the current experiments were short-term, and the long-term effects of feeding a $60 \%$ forage diet to high producing dairy cows using either AS or CS as the major forage on feed efficiency or even on milk composition or digestibility and fecal excretion of nutrients need to be investigated.

In the current experiments, increasing dietary forage level from 50 to $60 \%$ of ration DM decreased DMI or DMI as percentage of BW but maintained the same level of milk production, thereby improving feed efficiency. In general, feed intake and milk production are inversely related to an increasing level of forage or concentration of NDF in the diet. Several studies reported decreased DMI and milk yield by increasing dietary forage level from 35 to $60 \%$ (Yang and Beauchemin, 2007 ) or from 50 to $60 \%$ of ration DM (Whitlock et al., 2003) or by increasing dietary NDF concentration from 26 to $34 \%$ (Beauchemin and Buchanan-Smith, 1989) or from 31 to $39 \%$ of ration DM (Ruiz et al., 1995). The decreased milk production, as observed in studies discussed above, was likely a consequence of a lower intake of DM and digestible OM in the total tract (Yang and Beauchemin, 2007). In contrast, a decrease in milk yield was absent in the current experiments. A lower intake of DM found for cows fed $60 \%$ forage diets in the current experiments was likely due to the rumen filling effect from more forage NDF being ingested by feeding a higher forage diet (Llamas-Lamas and Combs, 1991). The diet NDF concentration (total and forage NDF) for all experimental diets used in the present study were equal to or exceed the recommendations suggested by NRC (2001). Within each experiment, diets were formulated to have the same concentration of dietary NDF; however, higher forage diets had more fiber from forages. Van Soest (1965) suggested that forage NDF content is an important factor in the regulation of forage intake. Therefore, the greater forage NDF content could be of major importance in the reduced DMI for cows fed a greater forage diet. A reason why milk yield in the current experiments was not decreased by a lower intake of DM could be that nutrient requirements of cows fed the $60 \%$ forage diets were met even at a lower intake of DM.

A key factor in establishing a high dietary forage feeding system is to use high quality (greater digestibility) forages (Llamas-Lamas and Combs, 1991) with proper forage particle length, as the forages used in the current experiments. Legumes seem to be a more adequate candidate than perennial grasses for use in high forage feeding systems due to a less rumen filling effect compared with grasses (Allen, 2000). 
Feeding a higher forage diet seems to increase digestibility of NDF in the total tract, as observed in Exp. 1. Moorby et al. (2006) reported a linear increase in apparent total-tract and rumen digestibility of NDF at dietary forage levels of $35,50,65$, and $80 \%$ of ration DM. Yang and Beauchemin (2007) reported results similar to Moorby et al. (2006) in that digestibility of NDF in the total tract was improved by increasing dietary forage level from 35 to $60 \%$; this increase in the totaltract digestibility of NDF was due to a higher ruminal rather than intestinal NDF digestion. A lower DMI by feeding more dietary forage allows larger particles to stay in the rumen longer than diets with less forage or fiber from byproduct feeds, thereby reducing the passage rate of fiber (Jung and Allen, 1995). As retention of fiber particles in the rumen increases, microbial populations may have more opportunity to attach to and degrade these fiber particles, resulting in increased fiber digestibility.

Higher dietary concentrate feeding, when compared with higher dietary forage feeding, often resulted in lower milk fat percentage, as observed in Exp. 1 and other studies (Whitlock et al., 2003; Yang and Beauchemin, 2007). A lower milk fat percentage from decreasing the forage to concentrate ratio could be explained by changes in rumen fermentation, because the proportion of propionate increases and $\mathrm{pH}$ of rumen decreases from feeding more concentrate in the diet (Yang and Beauchemin, 2007). However, based on the level of milk production (47 vs. $46 \mathrm{~kg} / \mathrm{d}$ ), the milk fat level (3.4 vs. $3.5 \%$ ) was acceptable and not considered low for cows fed 50 vs. $60 \%$ forage diets, respectively, in Exp. 1.

\section{Monensin Supplementation}

In the present experiments, supplementation of monensin had minimal effects on animal performance, except for a decrease in percentages of milk fat and protein for cows fed the higher forage diet (60\% ration DM) using AS as the major forage. Supplementation of monensin has been shown to decrease milk fat percentage (Ramanzin et al., 1997; Phipps et al., 2000) but not total milk fat yield (McGuffey et al., 2001). The reduced ruminal production of acetate and butyrate is frequently attributed as the main factor reducing milk fat percentage when cows are fed diets supplemented with monensin (Van Der Werf et al., 1998). Fellner et al. (1997) reported that monensin inhibited the rate of biohydrogenation of long chain fatty acids, which can inhibit the de novo synthesis of fatty acids in the mammary gland (Bauman and Griinari, 2003), and therefore reduced milk fat output when cows were fed diets supplemented with monensin (Ipharraguerre and Clark, 2003). Information related to the profiles for
VFA in the rumen and long chain fatty acids in milk may be needed to explain changes in milk fat percentage for cows fed a higher forage diet using AS as the major forage in the first experiment.

In the literature, monensin seems to decrease milk protein percentage; however, this inhibitory effect of monensin was likely a dilution effect of increased milk yield when monensin was supplemented (Ipharraguerre and Clark, 2003). In Exp. 1, yields of milk and milk protein were similar between dietary treatments and therefore a dilution effect of milk yield on milk protein percentage was unlikely. A reason why milk protein percentage was decreased when supplementing monensin to $60 \%$, but not $50 \%$, forage diets could be the numerically lower dietary intake of DM and $\mathrm{N}$ observed for cows fed the $60 \%$ forage diet supplemented with monensin. A reduced intake of dietary DM and N could result in less nutrients reaching the small intestine, thereby potentially limiting amino acids available for absorption by the small intestine to be used for milk protein synthesis (Sniffen and Robinson, 1987). In addition to less amino acids reaching the small intestine, slower passage rates by increasing dietary forage level could decrease the amount of bacteria leaving the rumen and thereby providing less $\mathrm{N}$ from microbial protein synthesis.

\section{CONCLUSIONS}

Results from these 2 experiments suggest that, when compared with rations containing $50 \%$ of ration DM from forages, cows fed a $60 \%$ forage diet consisting of alfalfa silage or corn silage as the major forage were able to maintain milk production while improving or maintaining the efficiency of converting feed to milk and the apparent efficiency of utilization of feed $\mathrm{N}$. Cows receiving a $60 \%$ forage diet had similar or improved digestibilities of DM, CP, and NDF with similar or reduced fecal excretions of DM and $\mathrm{N}$ compared with cows fed a $50 \%$ forage diet. Effects of monensin under the conditions of the current experiments were minimal.

\section{ACKNOWLEDGMENTS}

We thank T. W. Cassidy and K. S. Heyler for technical assistance and the staff at The Pennsylvania State University Dairy Cattle Research and Education Center (University Park, PA) for feeding and care of cows.

\section{REFERENCES}

Allen, M. S. 2000. Effects of diet on short-term regulation of feed intake by lactating dairy cattle. J. Dairy Sci. 83:1598-1624.

AOAC. 2000. Official Methods of Analysis. 17th ed. Association of Official Analytical Chemists Int., Gaithersburg, MD. 
AOAC. 2005. Official Methods of Analysis. 18th ed. Association of Official Analytical Chemists Int., Gaithersburg, MD.

Bailey, K. W., C. M. Jones, and A. J. Heinrichs. 2005. Economic returns to Holstein and Jersey herds under multiple component pricing. J. Dairy Sci. 88:2269-2280.

Bauman, D. E., and J. M. Griinari. 2003. Nutritional regulation of milk fat synthesis. Annu. Rev. Nutr. 23:203-227.

Beauchemin, K. A., and J. G. Buchanan-Smith. 1989. Effects of dietary neutral detergent fiber concentration and supplementary long hay on chewing activities and milk production of dairy cows. J. Dairy Sci. 72:2288-2300.

Brito, A. F., and G. A. Broderick. 2006. Effect of varying dietary ratios of alfalfa silage to corn silage on production and nitrogen utilization in lactating dairy cows. J. Dairy Sci. 89:3924-3938.

Cherney, D. J. R., J. H. Cherney, and L. E. Chase. 2004. Lactation performance of Holstein cows fed fescue, orchardgrass, or alfalfa silage. J. Dairy Sci. 87:2268-2276.

Duffield, T. F., and R. N. Bagg. 2000. Use of ionophores in lactating dairy cattle: A review. Can. Vet. J. 41:388-394.

Fellner, V., F. D. Sauer, and J. K. G. Kramer. 1997. Effect of nigericin, monensin, and tetronasin on biohydrogenation in continuous flowthrough ruminal fermenters. J. Dairy Sci. 80:921-928.

Gaines, W. L. 1928. The energy basis of measuring milk yield in dairy cows. Pages 403-438 in Agric. Exp. Stn. Bull. No. 308. Univ. Illinois, Urbana-Champaign.

Goering, H. K., and P. J. Van Soest. 1970. Forage Fiber Analyses (Apparatus, Reagents, Procedures, and Some Applications). Agric. Handbook 379. ARS-USDA, Washington, DC.

Huhtanen, P., K. Kaustell, and S. Jaakkola. 1994. The use of internal markers to predict total digestibility and duodenal flow of nutrients in cattle given six different diets. Anim. Feed Sci. Technol. 48:211-227.

Ipharraguerre, I. R., and J. H. Clark. 2003. Usefulness of ionophores for lactating dairy cows: A review. Anim. Feed Sci. Technol. 106:39-57.

Jung, H. G., and M. S. Allen. 1995. Characteristics of plant-cell walls affecting intake and digestibility of forages by ruminants. J. Anim. Sci. 73:2774-2790.

Kononoff, P. J., and A. J. Heinrichs. 2004. TMR particle size analysis and interpretation. Pages 167-171 in Proc. Cornell Nutr. Conf Cornell Univ., Ithaca, NY.

Llamas-Lamas, G., and D. K. Combs. 1991. Effect of forage to concentrate ratio and intake level on utilization of early vegetative alfalfa silage by dairy cows. J. Dairy Sci. 74:526-536.

Lykos, T., and G. A. Varga. 1995. Effects of processing method on degradation characteristics of protein and carbohydrate sources in situ. J. Dairy Sci. 78:1789-1801.

McGuffey, R. K., L. F. Richardson, and J. I. D. Wilkinson. 2001. Ionophores for dairy cattle: Current status and future outlook. J. Dairy Sci. 84:E194-E203.

Moorby, J. M., R. J. Dewhurst, R. T. Evans, and J. L. Danelon. 2006. Effects of dairy cow diet forage proportion on duodenal nutrient supply and urinary purine derivative excretion. J. Dairy Sci. 89:3552-3562.

NRC. 2001. Nutrient Requirements of Dairy Cattle. 7th rev. ed. Natl. Acad. Sci., Washington, DC.

Phipps, R. H., J. I. D. Wilkinson, L. J. Jonker, M. Tarrant, A. K. Jones, and A. Hodge. 2000. Effect of monensin on milk production of Holstein-Friesian dairy cows. J. Dairy Sci. 83:2789-2794.

Ramanzin, M., L. Bailoni, S. Schiavon, and G. Bittante. 1997. Effect of monensin on milk production and efficiency of dairy cows fed two diets differing in forage to concentrate ratios. J. Dairy Sci. 80:1136-1142.

Roe, M. B., and C. J. Sniffen. 1990. Techniques for measuring protein fractions in feedstuffs. Pages 81-88 in Proc. Cornell Nutr. Conf., Cornell Univ., Ithaca, NY.

Ruiz, R., G. L. Albrecht, L. O. Tedeschi, G. Jarvis, J. B. Russell, and D. G. Fox. 2001. Effect of monensin on the performance and nitrogen utilization of lactating dairy cows consuming fresh forage. J. Dairy Sci. 84:1717-1727.

Ruiz, T. M., E. Bernal, C. R. Staples, L. E. Sollenberger, and R. N. Gallaher. 1995. Effect of dietary neutral detergent fiber concentration and forage source on performance of lactating cows. J. Dairy Sci. 78:305-319

Russell, J. B., and A. J. Houlihan. 2003. Ionophore resistance of ruminal bacteria and its potential impact on human health. FEMS Microbiol. Rev. 27:65-74

SAS Institute. 1999. SAS/STAT User's Guide: Statistics. Version 8 ed. SAS Institute Inc., Cary, NC.

Sniffen, C. J., and P. H. Robinson. 1987. Microbial growth and flow as influenced by dietary manipulations. J. Dairy Sci. 70:425-441.

Trinder, P. 1969. Determination of glucose in blood using glucose oxidase with an alternative oxygen acceptor. Ann. Clin. Biochem. 6:24-27.

USDA. 2006. Agricultural Marketing Service, Milk Marketing Order Statistics. http://www.fmmone.com/ Accessed Jan. 30, 2007.

Van Der Werf, J. H. J., L. J. Jonker, and J. K. Oldenbroek. 1998. Effect of monensin on milk production by Holstein and Jersey cows. J. Dairy Sci. 81:427-433.

Van Soest, P. J. 1965. Symposium on factors influencing the voluntary intake of herbage by ruminants: Voluntary intake in relation to chemical composition and digestibility. J. Anim. Sci. 24:834843

Van Soest, P. J., J. B. Robertson, and B. A. Lewis. 1991. Methods for dietary fiber, neutral detergent fiber and non-starch polysaccharides in relation to animal nutrition. J. Dairy Sci. 74:3583-3597.

Whitlock, L. A., D. J. Schingoethe, A. R. Hippen, K. F. Kalscheur, and A. A. AbuGhazaleh. 2003. Milk production and composition from cows fed high oil or conventional corn at two forage concentrations. J. Dairy Sci. 86:2428-2437.

Yang, W. Z., and K. A. Beauchemin. 2007. Altering physically effective fiber intake through forage proportion and particle length: Digestion and milk production. J. Dairy Sci. 90:3410-3421. 